\title{
TRANSLATION AND VALIDATION OF THE BRAZILIAN PORTUGUESE VERSION OF THE GASTROINTESTINAL SYMPTOM RATING SCALE (GSRS) QUESTIONNAIRE
}

\author{
Gabriela Santos SOUZA ${ }^{1}$, Fabiana Andrea Hoffmann SARDÁ1, Eliana Bistriche GIUNTINI², \\ Iara GUMBREVICIUS ${ }^{3}$, Mauro Batista de MORAIS ${ }^{4}$ and Elizabete Wenzel de MENEZES ${ }^{2,5}$
}

Received 27/1/2016

Accepted 7/3/2016

\begin{abstract}
Background - Bowel function is a widely evaluated parameter in interventional and longitudinal studies since it is associated with good maintenance of health. The evaluation of intestinal function has been performed by many questionnaires, however, there are few options validated in Brazilian Portuguese. Objective - The aim of this work was to translate and validate into Brazilian Portuguese the Gastrointestinal Symptom Rating Scale (GSRS) questionnaire. Methods - Translation and cultural adaptation were performed according to a previously established methodology followed by reliability calculations. Results - The final translated GSRS questionnaire showed an adequate value of overall reliability of Cronbach's alpha of 0.83 , and its domains were classified from acceptable to adequate. The overall test-retest reliability by intraclass correlation coefficient (ICC) was 0.84 , considered excellent. Conclusion - The GSRS was translated and validated into Brazilian Portuguese, with appropriate internal consistency and reliability and is available to be used in assessments of bowel function.

HEADINGS - Symptom assessment. Surveys and questionnaires. Gastrointestinal motility. Reproducibility of results. Translations. Validation studies.
\end{abstract}

\section{INTRODUCTION}

The proper functioning of the digestive tract is frequently evaluated in interventional and longitudinal studies and is related to maintenance of overall health and wellness of the individual. This function is not limited to digestion of foods and absorption of nutrients. Gastrointestinal disorders are quite common in both children and adults ${ }^{(5)}$ and, often they are not associated to a structural or biochemical reasons $\left.{ }^{(}\right)$. These disorders can negatively affect the quality of life of patients who report various gastrointestinal symptoms. In addition, there are factors that are frequently overlooked as an economic impact due to spending and degree of absenteeism $^{(3,24)}$. In the United States, from 2006 to 2011, there was an increase of $41.5 \%$ of people who had constipation and who sought the emergency service, increasing the domestic spending further $120 \%$ in the period, accounting for 1.6 billion dollars in $2011^{(31)}$.

Among the parameters studied to determine the proper bowel function are stool consistency, frequency of evacuation and the occurrence of gastrointestinal symptoms ${ }^{(6,34)}$. In general, the existing tools are used for the diagnosis of certain digestive diseases such as gastroesophageal reflux disease, irritable bowel syndrome, functional diarrhea, functional constipation and fecal incontinence, among others. However, there are few instruments translated and validated into Brazilian Portuguese. Among the options available, the following have been validated into Brazilian Portuguese: Bowel Disease Questionnaire $(B D S)^{(1)}$ and Bowel Function in the Community questionnaires $^{(12)}$; each one consisting of approximately 70 questions and referring to symptoms of diseases and gastrointestinal habits manifested in the period related to the previous year of applying the questionnaire. Due to the long period evaluated, the application of these instruments in short-term intervention studies is not appropriate. In this sense, the Gastrointestinal Symptom Rating Scale (GSRS) ${ }^{(32)}$ is the most appropriate tool for assessment of bowel function since it refers to the period of the previous week, requires a short time to fill and has easy-to-understand questions on gastrointestinal symptoms.

Declared conflict of interest of all authors: none

Disclosure of funding: Grant 2013/07914-8, São Paulo Research Foundation (FAPESP).

Souza GS is a recipient of a master scholarship form CNPq and Sardá FAH is a recipient of a doctoral scholarship from CAPES, both in the Food Science Post Graduation program at Faculty of Pharmaceutical Sciences at USP. Giuntini EB is a recipient of a post-doctoral scholarship from CAPES.

Work performed at: Departamento de Alimentos e Nutrição Experimental da Faculdade de Ciências Farmacêuticas, Universidade de São Paulo.

${ }^{1}$ Programa de Pós-graduação em Ciência dos Alimentos, Faculdade de Ciências Farmacêuticas, USP, São Paulo, SP, Brasil; ${ }^{2}$ Food Research Center (FoRC/Cepid/Fapesp), Brasil;

${ }^{3}$ Programa de Pós-graduação em Nutrição Humana Aplicada Pronut/FCF/FEA/FSP - USP, São Paulo, SP, Brasil; ${ }^{4}$ Escola Paulista de Medicina, Universidade Federal de São Paulo, SP, Brasil. ${ }^{5}$ Departamento de Alimentos e Nutrição Experimental, Faculdade de Ciências Farmacêuticas, USP, São Paulo, SP, Brasil.

Correspondence: Elizabete Wenzel de Menezes. Av. Prof. Lineu Prestes, 580, bloco 14. CEP: 05508-000 - São Paulo, SP, Brasil. E-mail: wenzelde@usp.br 
Originally, the GSRS was developed in Sweden to assess patients with irritable bowel syndrome and peptic disease symptoms ${ }^{(32)}$. Later, its reliability and validity for other disorders in the same country were well documented ${ }^{(14)}$, as well as its applicability to the general population ${ }^{(15)}$.

The GSRS was translated and validated into English ${ }^{(28)}$, German, Hungarian, Italian, Polish, Spanish and Afrikaan ${ }^{(22)}$, and has been widely used to evaluate bowel function in interventional studies ${ }^{(2,21,23,29)}$, longitudinal studies $^{(16,30)}$ and the occurrence of gastrointestinal symptoms in celiac children ${ }^{(18)}$.

Considering the limited availability of instruments in Brazil that allow the assessment of gastrointestinal functioning related to the recent period in an easy and self-reportable way, the aim of this study was to translate and validate the GSRS questionnaire into Portuguese to be used in Brazil.

\section{METHODS}

The translation of the GSRS questionnaire was carried out as recommended by Beaton et al.(4). The Portuguese validated 36-item Short Form Health Survey ${ }^{(10)}$ was used as a validation reference. Both questionnaires were answered by volunteers with a two-week interval.

An Expert Reviewer Committee was established, composed by the following healthcare professionals: pharmacist, nutritionist, nurse, physician and biologist. The Committee discussed the purpose of the GSRS and its structure, the scope of questions and the most appropriate nomenclature, to make the questionnaire clear to understand and its reading easy and accessible and reviewed every version. A total of 155 volunteers of both genders ( $72 \%$ female), 18-60 years old, residents of the North (31\%), Southeast (53\%) and South $(16 \%)$ regions of Brazil participated. The retest was answered by 100 of the initial volunteers, with a two-week interval. This research was approved by the Ethical Research Committee of the Faculty of Pharmaceutical Science, University of São Paulo (USP) (CEP/FCF/194, CAAE 0042.0.018.000-11) according to the rules of the National Committee for Ethical Research of the Brazilian Health Ministry (CONEP/MS). All volunteers signed an informed consent form allowing participation and disclosure of results.

\section{Gastrointestinal Symptom Rating Scale (GSRS) questionnaire}

The GSRS is self-administered questionnaire and has 15 questions divided into 5 domains that cover the gastrointestinal system: diarrhea, constipation, abdominal pain, reflux and indigestion. The questionnaire answers are arranged according to the 7-point Likert scale, in which "1" indicates absence and "7" the higher frequency or intensity of the symptoms ${ }^{(28)}$. This tool has already been validated as to their questions and assessment scales (construct validity and criterion validity) ${ }^{(15,32)}$. The GSRS translating process for use in Brazil was done based on the GSRS English version $^{(28)}$, already adjusted for a 7-point scale.

\section{Translation and cultural adaptation}

The translation and cultural adaptation of the GSRS questionnaire ${ }^{(28,32)}$ was performed in steps according to a developed methodology ${ }^{(4)}$. The translation, synthesis and back-translation were performed as described in Figure 1. The original questionnaire and the versions created in the translation and backtranslation steps were evaluated by a certified sworn translator fluent in English, with Portuguese as their native language; all other professionals involved in the process were healthcare professionals. The pre-final version of the questionnaire was prepared by the translator after comparison of the versions and cultural adaptation of certain terminologies and was consolidated by the multidisciplinary team. To facilitate the application of the questionnaire a field below each question was provided to indicate the answers and possible comments. The pretest with this version was answered by a total of 20 volunteers of both genders (12 women) to assess the understanding of the questions. In the final stage of the test we had the participation of 155 volunteers and 100 in the retest.

The 36-item Short-Form Health Survey (SF-36) questionnaire was used as a validation reference. The general quality of life questionnaire SF-36 (self-administered) has 36 questions divided into 8 domains which can also be grouped in Physical Components and/or Mental Components. It was validated into Portuguese ${ }^{(10)}$ and has been used in other GSRS validation studies ${ }^{(22)}$.

\section{Psychometric properties and statistical analysis}

The psychometric properties of the Brazilian version of the GSRS questionnaire were evaluated using Statistica 10 software, through the following tests:

1. Test phase - The internal consistency of the definitive version of the questionnaire $(n=155)$ was calculated using Cronbach's alpha, which assesses the extent to which a set of items is related, within the same domain as the measurement ${ }^{(11)}$. Cronbach's alpha value can be classified as excellent $(>0.90)$, adequate $(0.70-0.90)$ and acceptable $(>0.60)^{(20,25)}$.

2. Retest phase - Reproducibility (test-retest stability) was evaluated from the retest administered to 100 volunteers after two weeks - that period was required so the volunteers would not remember the questions already answered, assuring careful rereading of the questionnaire, and so that there were no major changes to their habits ${ }^{(13)}$. The calculation was performed using the intra-class correlation coefficient (ICC), which measures the stability of a score after the same tool has been applied twice to the same individuals in similar conditions ${ }^{(20)}$. The correlation was considered satisfactory when $0.40 \leq$ ICC $<0.75$ and excellent when ICC $\geq 0.75^{(17)}$.

3. Construct validity test - Volunteers $(n=100)$ answered the GSRS questionnaire along with the general questionnaire for quality of life assessment SF-36 for the construct validity test. This process allows a measurement of a questionnaire to be compared to another measurement already considered a standard ${ }^{(20)}$. Calculations were performed using the Spearman correlation which can be classified as weak $(<0.30)$, moderate $(0.30-0.60)$ and strong $(>0.60)^{(22)}$. 


\begin{tabular}{|c|c|c|c|c|c|}
\hline Translation & Synthesis & $\begin{array}{l}\text { Back } \\
\text { inslatic }\end{array}$ & $\begin{array}{c}\text { Expert } \\
\text { Review } \\
\text { Committee }\end{array}$ & & $\begin{array}{c}\text { Testing/ } \\
\text { Retesting }\end{array}$ \\
\hline $\begin{array}{l}\text { - Two } \\
\text { independent } \\
\text { translations } \\
\text { into Portuguese } \\
\text { by Brazilian } \\
\text { translators, } \\
\text { fluent in } \\
\text { English }\end{array}$ & $\begin{array}{l}\text { - Resolve any } \\
\text { discrepancies } \\
\text { - Synthesis } \\
\text { into a single } \\
\text { Brazilian } \\
\text { Portuguese } \\
\text { version }\end{array}$ & $\begin{array}{l}\text { - Back } \\
\text { translation } \\
\text { into original } \\
\text { language by } \\
\text { translators who } \\
\text { are English- } \\
\text { native speakers } \\
\text { and fluent in } \\
\text { Portuguese }\end{array}$ & $\begin{array}{l}\text { - Review all } \\
\text { reports } \\
\text { - Reach } \\
\text { consensus on } \\
\text { discrepancies } \\
\text { - Produce } \\
\text { pre-final } \\
\text { version }\end{array}$ & $\begin{array}{l}\text { - Questionnaire } \\
\text { application to } \\
\text { evaluate the } \\
\text { questions } \\
\text { - Carrying out } \\
\text { structural } \\
\text { adjustments, if } \\
\text { necessary }\end{array}$ & $\begin{array}{l}\text { - Test and retest } \\
\text { application }\end{array}$ \\
\hline
\end{tabular}

FIGURE 1. Flow chart of the translation and cultural adaptation of the Gastrointestinal Symptom Rating Scale (GSRS) questionnaire into Brazilian Portuguese

\section{RESULTS}

The procedures for the translation, cultural adaptation and validation of the GSRS questionnaire in this study were carried out in stages, in an orderly fashion, with satisfactory results obtained. The process of translation and backtranslation showed no disagreement or need for significant changes in the vocabulary in order for the reader to achieve full understanding. This was favored due to the small number of questions and straightforward format of the questionnaire in English.

In the pretest phase the questionnaire showed no difficulty of understanding when it was answered by the volunteers, both in relation to questions and scales. So there was no need for structural or language adjustments for the final testing phase, only small layout changes were made. The time taken to fill out the GSRS questionnaire translated into Portuguese (Figure 2) varied between 5 and 10 minutes.
The value of overall internal consistency of the final version of the questionnaire, expressed by Cronbach's alpha was 0.83 which is considered adequate ${ }^{(25)}$ and its domains ranged from acceptable ( 0.65 for abdominal pain) to adequate $(0.79$ for diarrhea syndrome) (Table 1).

The overall reproducibility of the Brazilian version of the GSRS questionnaire was 0.84 which is considered excellent, as well as the reflux syndrome domain; the other 4 domains had lower values (Table 1).

The construct validity showed a negative correlation between the Mental Component domain of the SF-36 questionnaire and the following 4 of GSRS domains: moderate correlation with Abdominal Pain (0.30) and Reflux Syndrome (0.32) and weak correlation with Diarrhea Syndrome (0.16) and Constipation Syndrome (0.17). This test suggested that the less intense the symptoms evaluated by the GSRS questionnaire, the greater the quality of life assessed by the SF-36.

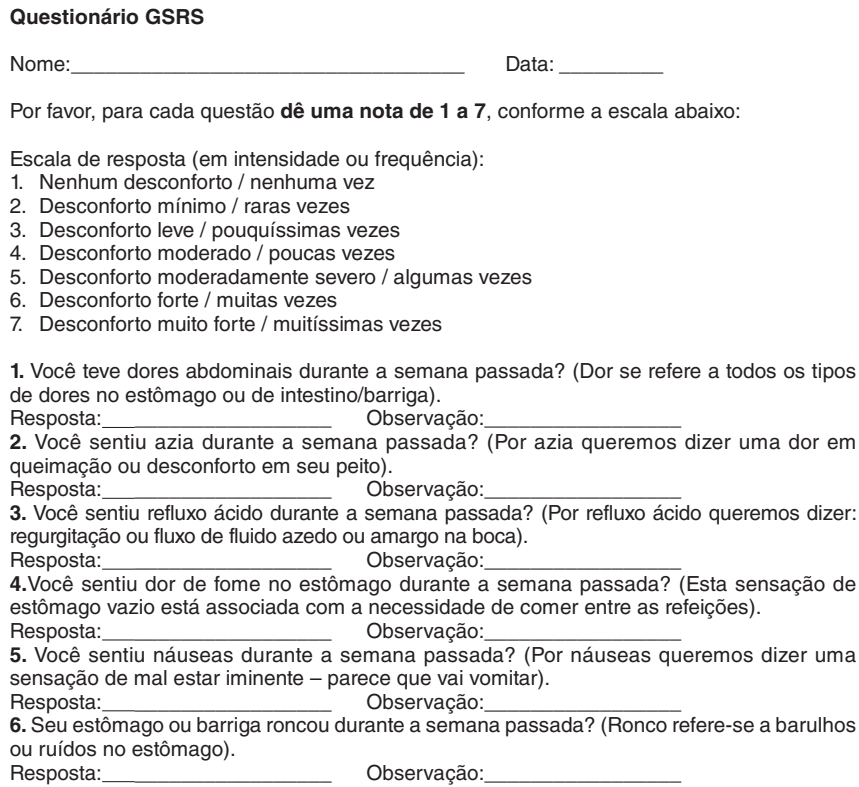

1. Você teve dores abdominais durante a semana passada? (Dor se refere a todos os tipos de dores no estômago ou de intestino/barriga).

7. Você sentiu o seu estômago cheio de ar durante a semana passada? (Sentir o estômago cheio de ar se refere ao inchaço no estômago ou barriga). Resposta:__ Observação: 8. Você arrotou durante a semana passada? (Arrotar refere-se a trazer ar ou gás através da boca).

FIGURE 2. Gastrointestinal Symptom Rating Scale (GSRS) questionnaire into Brazilian Portuguese 
TABLE 1. Internal consistency (Cronbach's alpha) and test-retest reliability (intraclass correlation coefficient (ICC)) values of the Brazilian Portuguese version of the Gastrointestinal Symptom Rating Scale questionnaire and values obtained in validations in other languages ${ }^{(1,2)}$.

\begin{tabular}{|c|c|c|c|c|c|c|c|c|c|}
\hline & $\begin{array}{l}\text { GSRS } \\
\text { Domain }\end{array}$ & $\begin{array}{l}\text { Brazilian } \\
\text { Portuguese }\end{array}$ & Afrikaans $^{1}$ & German $^{1}$ & Hungarian $^{1}$ & Italian $^{1}$ & Polish $^{1}$ & Spanish $^{1}$ & Enghish $^{2}$ \\
\hline \multirow{5}{*}{ Cronbach's alpha } & Abdominal pain & 0.65 & 0.60 & 0.43 & 0.59 & 0.65 & 0.49 & 0.45 & 0.62 \\
\hline & Reflux & 0.72 & 0.61 & 0.72 & 0.73 & 0.84 & 0.49 & 0.67 & 0.61 \\
\hline & Indigestion & 0.69 & 0.76 & 0.79 & 0.74 & 0.74 & 0.73 & 0.78 & 0.70 \\
\hline & Diarrhea & 0.79 & 0.75 & 0.84 & 0.79 & 0.72 & 0.78 & 0.82 & 0.83 \\
\hline & Constipation & 0.67 & 0.82 & 0.81 & 0.79 & 0.76 & 0.87 & 0.75 & 0.80 \\
\hline \multirow{5}{*}{ ICC } & Abdominal pain & 0.71 & 0.55 & 0.36 & 0.57 & NA & 0.45 & 0.48 & 0.51 \\
\hline & Reflux & 0.75 & 0.37 & 0.66 & 0.59 & NA & 0.61 & 0.62 & 0.42 \\
\hline & Indigestion & 0.55 & 0.46 & 0.61 & 0.75 & NA & 0.71 & 0.75 & 0.50 \\
\hline & Diarrhea & 0.55 & 0.56 & 0.67 & 0.70 & NA & 0.63 & 0.38 & 0.53 \\
\hline & Constipation & 0.64 & 0.71 & 0.60 & 0.72 & NA & 0.72 & 0.72 & 0.60 \\
\hline
\end{tabular}

${ }^{1}$ Adapted from ${ }^{(22)} .{ }^{2}$ Adapted from ${ }^{(28)}$. ICC: intraclass correlation coefficient; NA: not available.

\section{DISCUSSION}

For the diagnosis of intestinal constipation and other gastrointestinal problems there are already a number of instruments available but for the overall assessment of bowel function the task is not simple since it is a sum of symptoms and perceptions.

According to Bovenschen et al. ${ }^{(8)}$ the development of tools for assessing gastrointestinal symptoms was very significant in recent decades, and the confidence in data obtained from research indicates the importance of using validated instruments. Some questionnaires, however, did not undergo a validation process which should include correct understanding of the terminology by the volunteers, so it is important to include unambiguous definitions ${ }^{(8)}$. In order to avoid inadequate answers resulting from the misunderstanding of a question, examples, synonyms and definitions were kept in the Brazilian Portuguese version of the GSRS following the model adopted ${ }^{(28)}$.

A cultural adaptation process is indicated when the instrument is used in different countries, languages or times to reduce the risk of introducing bias in its application. There is no existing instrument adaptation protocol to use in another cultural environment, however, there is a consensus that it is totally inappropriate to literally translate a questionnaire and use it in another linguistic context ${ }^{(19)}$. In this work during translation and back-translation terminology covering the entire Brazilian territory was used preventing the need for regionalization.

According to Kulich et al. ${ }^{(22)}$, the GSRS is one of the best established, validated, sensitive and reliable questionnaires among the instruments available to evaluate gastrointestinal function and symptoms in studies and clinical trials since it has very good psychometric characteristics. The GSRS was one of the 39 questionnaires selected for evaluation of gastroesophageal reflux disease and despite being regarded as a generic questionnaire it was considered useful since it is self-administered and reliable. It can be used in studies within different countries since it has been validated in several languages ${ }^{(7)}$. These and other studies corroborate to the importance of validating this tool for use in the Brazilian population $^{(2,21,23,29)}$.

The results obtained regarding the psychometric properties of the GSRS translated into Brazilian Portuguese are similar to those found in previous investigations as in the validations performed by Revicki et al. ${ }^{(28)}$ in American English version of the GSRS and by Kulich et al. ${ }^{(22)}$ in the Afrikaans, Hungarian, Italian, German, Spanish and Polish versions, as shown in Table 1.

Similarly, as it was observed in other language validations, one of the highest values of Cronbach's alpha was for the Diarrhea Syndrome domain which in the Brazilian Portuguese GSRS version presented appropriate reliability (0.79). In parallel, the Abdominal Pain was the domain that showed the lowest value of Cronbach's Alpha, 0.65, similar to that found in other studies. This value indicates acceptable internal consistency and, although low, it is much higher than the value found in validations for the German (0.43), Polish (0.49) and Spanish languages $(0.45)^{(22)}$. Low internal consistency values can be attributed to the wide range of symptoms as well as to the small amount of items to assess these symptoms which in the case of Abdominal Pain were only two questions.

In the reproducibility evaluation, the GSRS showed overall excellent results (0.84), as well as in its Reflux Syndrome domain (0.75), which had a higher ICC result than other 
GSRS language validations ${ }^{(22)}$. Another domain that has positioned itself ahead of other versions of the GSRS was Abdominal Pain (0.71), with a reproducibility considered satisfactory. The other domains also had satisfactory results similar to those in other GSRS validations (Table 1).

Questionnaires regarding other issues were translated into Portuguese scoring grades above 0.70 , which are considered adequate for internal consistency. Pereira et al. ${ }^{(26)}$ found high internal consistency $(>0.70)$ for three of the four domains assessed (physical aspect, pain, sleep) by the HBQOL questionnaire (Heartburn Specific Quality of Life Instrument). Carvalho et al. ${ }^{(9)}$ translated and validated Male Body Dissatisfaction Scale (MBDS) into Portuguese, and obtained an internal consistency of 0.92 . Likewise, in this work the English Acronym of the questionnaire was maintained in order to be easily identified and recognized by the scientific community.

In the assessment of construct validity, the mental components of the SF-36 that showed a moderate correlation $(P<0.05)$ with the domains of GSRS are highlighted: Mental Health and Vitality, 0.37 and 0.34 relative to Abdominal Pain, and 0.32 and 0.31 relative to reflux syndrome, respectively. These values suggest that even in healthy volunteers the presence of symptoms of abdominal pain and reflux cause disturbance and adversely affect the well-being of an individual. The domain of GSRS questionnaire in six languages ${ }^{(22)}$ also showed a negative correlation with SF-36, being significant and most remarkable for the Abdominal Pain domain which ranged from 0.36 to 0.45 . In Revicki et al. ${ }^{(28)}$, the Abdominal Pain domain showed the strongest correlation ( $\mathrm{r}=0.44 ; P<0.0001)$ with the scales of the SF-36, especially with Body Pain and Vitality.

In this study, the only item of the Physical Component that correlated with the GSRS domains was Body Pain, ranging from mild to moderate in relation to the Abdominal Pain (0.32), Reflux Syndrome (0.25) Diarrhea Syndrome (0.16), and Constipation Syndrome (0.26) domains. The items RolePhysical and Physical Functioning did not correlate with any domain of the GSRS, demonstrating that the gastrointestinal symptoms reported by healthy volunteers caused no physical limitations that would preclude the development of daily activities. Even patients with dyspepsia symptoms show very low correlation scores between GSRS and Role-Physical and Physical Functioning ${ }^{(22)}$.

The SF-36 was used for validation of other questionnaires related to the gastrointestinal system in Brazil, the Fecal Incontinence Quality of Life (FIQL) $)^{(35)}$ and Inflammatory Bowel Questionnaire Disease (IBQD) ${ }^{(27)}$. Both questionnaires showed good and moderate correlations with the SF-36. In FIQL it was also observed that quality of life parameters of patients with fecal incontinence are lower compared to healthy volunteers or volunteers with intestinal constipation ${ }^{(35)}$ The consolidation of use of the GSRS allows this questionnaire to be used in the validation of other instruments, such as the Global Overall Symptom (GOS) Scale, considered a simple method to evaluate dyspepsia symptoms in clinical trials. To assist in the GOS's validation this new tool was compared to GSRS and also to Overall Treatment Effect (OTE), Quality of Life in Reflux and Dyspepsia (QoLRAD) questionnaire and Reflux Disease Questionnaire (RDQ) for 2 and 28 days $^{(33)}$.

In literature review article concerning questionnaires to assess gastroesophageal reflux disease, fourteen instruments used to assess treatment applied to patients were found, and GRSR is the only one named as having the ability to discriminate both severity and frequency of different gastrointestinal symptoms. The majority assesses specific symptoms such as reflux, dysphagia, regurgitation, dyspepsia ${ }^{(7)}$.

All aspects assessed to validate the GSRS questionnaire in Brazilian Portuguese showed suitable results according to each parameter thus indicating that the instrument showed excellent reproducibility and internal consistency, it is easy to understand and quick to fill out by the person answering the questions and may be useful in clinical trials and laboratory services for the evaluation of gastrointestinal symptoms.

\section{CONCLUSION}

The GSRS questionnaire was translated and validated into Brazilian Portuguese with appropriate reliability and excellent reproducibility and it is now available for use in evaluation and research on gastrointestinal functioning.

\section{ACKNOWLEDGMENT}

We would like to acknowledge all those who directly or indirectly contributed to this study, in particular the volunteers.

\section{Authors' contributions}

Souza GS: contributed to data collection, tabulation and analysis, interpretation of results, literature review and writing of the article. Sardá FAH: contributed to project conception, data collection and analysis, interpretation of results and writing of the article. Both Sardá FAH and Souza GS contributed equally to this article. Giuntini EB: contributed to the analysis and interpretation of results, writing of the article. Gumbrevicius I: participated in literature review and critical review of the manuscript. Morais MB: contributed to critical review. Menezes EW: contributed to project conception and critical review. All the authors approved the final version of the manuscript to be submitted. 
Souza GS, Sardá FAH, Giuntini EB, Gumbrevicius I, Morais MB, Menezes EW. Tradução e validação da versão brasileira do questionário Gastrointestinal Symptom Rating Scale (GSRS). Arq Gastroenterol. 2016,53(3):146-51.

RESUMO - Contexto - O funcionamento intestinal é um dos parâmetros amplamente avaliado em estudos intervencionais e longitudinais, pois está associado à manutenção da saúde. A avaliação do funcionamento intestinal tem sido realizada por diferentes questionários, mas são poucas as alternativas validadas em português. Objetivo - O objetivo deste trabalho foi traduzir e validar para a língua portuguesa (Brasil) o questionário Gastrointestinal Symptom Rating Scale (GSRS). Métodos - A tradução e adaptação cultural foram realizadas de acordo com metodologia previamente estabelecida, seguida dos cálculos de confiabilidade. Resultados - A aplicação do questionário GSRS traduzido apresentou valor de confiabilidade geral alfa de Cronbach de 0,83, classificado como adequado, e seus domínios foram classificados de aceitável a adequado; o teste-reteste geral apresentou coeficiente de correlação intraclasse de 0,84 , considerado excelente. Conclusão - O GSRS foi traduzido e validado para Português (Brasil), apresentando confiabilidade e reprodutibilidade apropriadas, e está disponível para ser utilizado em avaliações de funcionamento intestinal.

DESCRITORES - Avaliação de sintomas. Inquéritos e questionários. Motilidade gastrointestinal. Reprodutibilidade dos testes. Traduções. Estudos de validação.

\section{REFERENCES}

1. Aires MT, Werneck GL. [Portuguese-language cultural adaptation and translation of "The Bowel Disease Questionnaire" used to assess functional bowel disorders]. Arq Gastroenterol. 2006;43:138-53.

2. Akamaru Y, Takahashi T, Nishida T, Omori T, Nishikawa K, Mikata S, et al. Effects of Daikenchuto, a Japanese Herb, on Intestinal Motility After Total Gastrectomy: a Prospective Randomized Trial. J Gastrointest Surg. 2015;19:467-72.

3. Bang CS, Kim YS, Han JH, Lee YS, Baik GH, Kim JB, et al. Functional Gastrointestinal Disorders in Young Military Men. Gut Liver. 2015;9:509-15.

4. Beaton DE, Bombardier C, Guillemin F, Ferraz MB. Guidelines for the process of cross-cultural adaptation of self-report measures. Spine (Phila Pa 1976). 2000;25:3186-91.

5. Bharucha AE, Pemberton JH, Locke GR. American Gastroenterological Association technical review on constipation. Gastroenterology. 2013;144:218-38.

6. Bischoff SC. 'Gut health': a new objective in medicine? BMC Med. 2011;9:24.

7. Bolier EA, Kessing BF, Smout AJ, Bredenoord AJ. Systematic review: questionnaires for assessment of gastroesophageal reflux disease. Dis Esophagus. 2015;28:105-20.

8. Bovenschen HJ, Janssen MJ, van Oijen MG, Laheij RJ, van Rossum LG, Jansen JB. Evaluation of a gastrointestinal symptoms questionnaire. Dig Dis Sci. 2006;51:1509-15.

9. Carvalho PH, Ferreira ME, Kotait M, Teixeira PC, Hearst N, Cordás TA, et al. [Conceptual, semantic, and instrumental equivalences: preliminary analysis of the Brazilian Portuguese version of the Male Body Dissatisfaction Scale (MBDS)]. Cad Saude Publica. 2013;29:403-9.

10. Ciconelli R, Ferraz M, Santos W, Meinão I, Marina R. Tradução para a Língua Portuguesa e validação do questionário genérico de avaliação de qualidade de vida SF-36 (Brasil SF-36). Revista Brasileira de Reumatologia. 1999;39:8.

11. Cronbach L. Coefficient Alpha and the internal structure of tests. Psychometrika. 1951;16:37.

12. de Cássia Domansky R, de Gouveia Santos VL. Cross-cultural adaptation and validation of the Portuguese version of the Bowel Function in the Community instrument. J Wound Ostomy Continence Nurs. 2007;34:671-7.

13. Digesu GA, Panayi D, Kundi N, Tekkis P, Fernando R, Khullar V. Validity of the Rome III Criteria in assessing constipation in women. Int Urogynecol J. 2010;21:1185-93.

14. Dimenäs E, Glise H, Hallerbäck B, Hernqvist H, Svedlund J, Wiklund I. Well-being and gastrointestinal symptoms among patients referred to endoscopy owing to suspected duodenal ulcer. Scand J Gastroenterol. 1995;30:1046-52.

15. Dimenäs E, Carlsson G, Glise H, Israelsson B, Wiklund I. Relevance of norm values as part of the documentation of quality of life instruments for use in upper gastrointestinal disease. Scand J Gastroenterol Suppl. 1996;221:8-13.

16. Dong R, Guo ZY, Ding JR, Zhou YY, Wu H. Gastrointestinal symptoms: a comparison between patients undergoing peritoneal dialysis and hemodialysis. World J Gastroenterol. 2014;20:11370-5.

17. Fleiss JL. The Design and Analysis of Clinical Experiments. New York: Wiley; 1986.

18. Gatti S, Caporelli N, Galeazzi T, Francavilla R, Barbato M, Roggero P, et al. Oats in the diet of children with celiac disease: preliminary results of a double-blind, randomized, placebo-controlled multicenter Italian study. Nutrients. 2013;5:4653-64.

19. Gjersing L, Caplehorn JR, Clausen T. Cross-cultural adaptation of research instruments: language, setting, time and statistical considerations. BMC Med Res Methodol. 2010;10:13.
20. Jensen MP. Questionnaire validation: a brief guide for readers of the research literature. Clin J Pain. 2003;19:345-52.

21. Kalaitzakis E, Josefsson A, Castedal M, Henfridsson P, Bengtsson M, Andersson B, et al. Gastrointestinal symptoms in patients with cirrhosis: a longitudinal study before and after liver transplantation. Scand J Gastroenterol. 2013;48:1308-16.

22. Kulich KR, Madisch A, Pacini F, Piqué JM, Regula J, Van Rensburg CJ, et al Reliability and validity of the Gastrointestinal Symptom Rating Scale (GSRS) and Quality of Life in Reflux and Dyspepsia (QOLRAD) questionnaire in dyspepsia: a six-country study. Health Qual Life Outcomes. 2008;6:12.

23. Kurppa K, Paavola A, Collin P, Sievänen H, Laurila K, Huhtala H, et al. Benefits of a Gluten-free diet for Asymptomatic Patients with Serologic Markers of Celiac Disease. Gastroenterology. 2014;147:610-617.e1.

24. López-Colombo A, Morgan D, Bravo-González D, Montiel-Jarquín A, Méndez-Martínez S, Schmulson M. The epidemiology of functional gastrointestinal disorders in Mexico: a population-based study. Gastroenterol Res Pract. 2012;2012:606174

25. Maroco J, Garcia-Marques T. Qual a fiabilidade do alfa de Cronbach? Questões antigas e soluções modernas? Laboratório de Psicologia. 2006;4:25.

26. Pereira GI, Costa CD, Geocze L, Borim AA, Ciconelli RM, Camacho-Lobato L. [Cross-cultural adaptation and validation for Portuguese (Brazil) of health related quality of life instruments specific for gastroesophageal reflux disease]. Arq Gastroenterol. 2007;44:168-77.

27. Pontes RM, Miszputen SJ, Ferreira-Filho OF, Miranda C, Ferraz MB. [Quality of life in patients with inflammatory bowel diseases: translation to Portuguese language and validation of the "Inflammatory Bowel Disease Questionnaire" (IBDQ)]. Arq Gastroenterol. 2004;41:137-43.

28. Revicki DA, Wood M, Wiklund I, Crawley J. Reliability and validity of the Gastrointestinal Symptom Rating Scale in patients with gastroesophageal reflux disease. Qual Life Res. 1998;7:75-83.

29. Riezzo G, Orlando A, D'Attoma B, Guerra V, Valerio F, Lavermicocca P, et al. Randomised clinical trial: efficacy of Lactobacillus paracasei-enriched artichokes in the treatment of patients with functional constipation--a double-blind, controlled, crossover study. Aliment Pharmacol Ther. 2012;35:441-50.

30. Salmean YA, Zello GA, Dahl WJ. Foods with added fiber improve stool frequency in individuals with chronic kidney disease with no impact on appetite or overall quality of life. BMC Res Notes. 2013;6:510.

31. Sommers T, Corban C, Sengupta N, Jones M, Cheng V, Bollom A, et al. Emergency department burden of constipation in the United States from 2006 to 2011. Am J Gastroenterol. 2015;110:572-9.

32. Svedlund J, Sjödin I, Dotevall G. GSRS--a clinical rating scale for gastrointestinal symptoms in patients with irritable bowel syndrome and peptic ulcer disease. Dig Dis Sci. 1988;33:129-34.

33. Veldhuyzen van Zanten SJ, Chiba N, Armstrong D, Barkun AN, Thomson AB, Mann V, et al. Validation of a 7-point Global Overall Symptom scale to measure the severity of dyspepsia symptoms in clinical trials. Aliment Pharmacol Ther. 2006;23:521-9.

34. Warschburger P, Hänig J, Friedt M, Posovszky C, Schier M, Calvano C. Health-related quality of life in children with abdominal pain due to functional or organic gastrointestinal disorders. J Pediatr Psychol. 2014;39:45-54.

35. Yusuf SA, Jorge JM, Habr-Gama A, Kiss DR, Gama Rodrigues J. [Evaluation of quality of life in anal incontinence: validation of the questionnaire FIQL (Fecal Incontinence Quality of Life)]. Arq Gastroenterol. 2004;41:202-8. 